\title{
28 Resarch Soure \\ Eco-Friendly Preparation and Characterization of Bioplastic Films from Marine Fish Wastes
}

Parthasarathy Surya

Annamalai University Faculty of Marine Sciences

Sundaramanickam Arumugam ( $\nabla$ fish_lar@yahoo.com )

Annamalai University https://orcid.org/0000-0002-2682-445X

Ajith Nithin

Annamalai University Faculty of Marine Sciences

Parthasarathy Iswarya

Annamalai University Faculty of Marine Sciences

\section{Research Article}

Keywords: Fish scales, Bioplastic film, SEM, FTIR, XRD, Biodegradability

Posted Date: November 15th, 2021

DOl: https://doi.org/10.21203/rs.3.rs-982850/v1

License: (c) (i) This work is licensed under a Creative Commons Attribution 4.0 International License. Read Full License 


\section{Abstract}

Synthetic plastics are highly hazardous contaminants; hence they must be replaced with alternatives. This study aimed to prepare corn starch-based bioplastics using fish scale through film casting technique as an alternative to synthetic plastics. In this work, four types of bioplastic films containing different percentages of fish-scale powder and corn starch were prepared. Physical and chemical properties such as texture, color, solubility in hot water, tensile strength, organic content, and morphology of all the four types of the synthesized biopolymer were analyzed. The mixture of fish-scale powder and corn-flour powder in the ratio of 1:3 yielded the best results. In the biodegradability test, degradation was noticed after 7 days of treatment with organic waste. The degradation was confirmed by surface changes in the morphology and the development of Aspergillus sp. The produced bioplastics were synthesized from ecofriendly, inexpensive, and natural materials. Thus, the present research has provided a viable alternative to synthetic plastics.

\section{Introduction}

Petroleum-derived plastics are conventionally used in almost all domestic and industrial applications owing to their excellent mechanical properties that act as a barrier against water and gas. However, their non-degradability coupled with the ability to accumulate and transfer toxicants has led several researchers to develop biopolymer-based plastics to ensure the sustainable and eco-friendly use of plastics (Hanani et al., 2012). Bioplastics can be distinguished as bio-based and biodegradable plastics. The bio-based plastics or biopolymers are synthesized from living organisms. Current bioplastic production represents around $1 \%$ of the annual plastic production (368 million tons) in the world (European Bioplastics. Bioplastics Market Data, 2021). Bio-based compounds include polysaccharides (starch, cellulose, pectin, and chitin), proteins (wheat gluten, wool, silk, casein, and gelatin), lipids (animal fats and plant oils), and products of microorganisms (polyhydroxyalkanoates) (PHA) such as polyhydroxybutyrate (PHB). The important sources of polymers are biomass-derived monomers, microorganism-derived monomers, and bio-derived monomers (Gatea et al., 2018). Among the three categories of polymers, starch, wheat, whey molasses, and sewage sludge serve as economically viable carbon sources that are renewable and biodegradable (Kumar et al., 2018). Biotechnology has been successfully employed in synthesizing many types of bioplastics for various applications, especially in the medical fraternity (Chen et al., 2018). With this view in mind, numerous strategies have been developed to maximize the production of bioplastics that are affordable and have properties comparable to those of synthetic plastics (Hassan et al., 2019).

Most of the bioplastics are produced from plant-based natural polymers such as starch, proteins, fatty acids, and disaccharides. The main limiting factor in bioplastic production is the availability of low-cost raw materials. The work on animal-based bioplastics is very much limited. Most of the research has been performed on microbial synthesis of bioplastics from agricultural (Getachew and Woldesenbet, 2016) and marine-based materials (Mostafa et al., 2020). 
The global fish production is witnessing an increasing trend, and the annual capture fishery production exceeded 150 million tons (FAO, 2018). This huge production also involves the generation of fishery byproducts. Parts of fishes such as head, skin, scales, skeletons, viscera, etc., amounting to $25-75 \%$ (Olsen et al., 2014), were discarded as waste. The scale constitutes around $5 \%$ of the whole fish (Villamil et al., 2017).

India, with its vast coastline, has a never-ending supply of fish-scale (FS) wastes. The abundant availability and renewability of these scales have made researchers turn their attention toward the valorization of FS waste. Hence, the synthesis of bioplastics was attempted by combining FS wastes and corn starch (CS) using glycerol as a plasticizer. In this study, the major ingredients used were whole discarded FS (irrespective of species) and CS.

\section{Materials And Methods}

\subsection{Collection of samples}

FS were sourced from the fishery wastes at Parangipettai fish market in Cuddalore District located in the Southeast coast of India. The scales were collected in zip-lock pouches, which were transported immediately to the laboratory and stored at $-20^{\circ} \mathrm{C}$ until analysis. The other two major ingredients for the study were Corn starch and glycerol $(99.5 \%)$. The CS was purchased from the local market and glycerol as well as other analytical chemicals was procured from Merck Ltd., Mumbai, India.

\subsection{Preparation of fish scales}

In the laboratory, the collected FS were cleaned thoroughly with Milli-Q water to remove the impurities. Furthermore, the FS were treated using different chemical composites, i.e., $1.0 \mathrm{M} \mathrm{NaCl}, 0.05 \mathrm{M} \mathrm{Tris} \mathrm{HCl}$, and $20.0 \mathrm{mM}$ EDTA for $48 \mathrm{~h}$ with an adjustable $\mathrm{pH}$ of 7.5. This process was intended to remove the proteins and other substances that are attached to the FS (Pati et al., 2010). Subsequently, the cleaned FS were dried in a hot air oven (Technico) at $70^{\circ} \mathrm{C}$ for $24 \mathrm{~h}$, and the dried FS were powdered by using a Fritsch planetary Ball mill (Glen crestan Ltd) until very fine particles were obtained. The obtained fine particles were sieved with a $45 \mu \mathrm{m}$ mesh sieve by using a mechanical sieve shaker (Jayant Gyratory sieve shaker) and again dried in a hot air oven and stored in a desiccator to avoid moisture absorbance for further processing.

\subsection{Preparation of film-forming solution and film casting}

FS and CS powders were the major ingredients for bioplastic film synthesis. In this study, these two substances were selected at four different ratios, i.e., type1-CS: $10 \mathrm{~g}$ pure CS as control, type2-CSFS1: 2.5 g FS and $7.5 \mathrm{~g}$ CS, type3-CSFS2: $5 \mathrm{~g}$ FS and $5 \mathrm{~g}$ CS, type4-FS: $10 \mathrm{~g}$ FS alone. All the samples were individually prepared by mixing $100 \mathrm{ml}$ of distilled water and $6 \mathrm{ml}$ of glycerol according to the method of 
Thammahiwes et al. (2017) with a few modifications. The mixture was heated to $90^{\circ} \mathrm{C}$ and stirred for 30 min using a magnetic stirrer with a hot plate.

The film-forming solution was cast onto a rimmed silicone resin plate $(50 \times 50 \mathrm{~mm})$, and air was blown over the plate for $12 \mathrm{~h}$ at room temperature. The resulting films were manually peeled off and used for further analyses (Arfat et al., 2014).

\subsection{Characterization of bioplastic films \\ 2.4.1. Texture, color, and hot water solubility}

Texture and color of the synthesized bioplastics were determined manually by sensorial evaluation, while hot water solubility was tested by boiling $10 \mathrm{~g}$ of each bioplastic film in $100 \mathrm{~mL}$ of water for $1 \mathrm{~h}$ at $90^{\circ} \mathrm{C}$ (Oluwasina et al., 2019).

\subsubsection{Moisture content}

To test the moisture content, $5 \mathrm{~g}$ of bioplastic film $(2 \mathrm{~cm} \times 2 \mathrm{~cm})$ was weighed $\left(\mathrm{W}_{1}\right)$, heated at $105^{\circ} \mathrm{C}$ for 3 $h$, placed in a desiccator to cool it down, and its weight was re-determined $\left(W_{2}\right)$ (Oluwasina et al., 2019).

This estimation was done in triplicates, and moisture loss was calculated as follows:

$\mathrm{Eq}(1)$ :

Moisture Content $(\%)=w_{1}-w_{2} / w_{1} \times 100$

Where, $W_{1}$ is the initial weight of the bioplastic film and $W_{2}$ is the final weight

\subsubsection{Opacity}

UV-VIS Spectrophotometer (SHIMADZU, UV-1800 (Asia Pacific PVT LTD, Singapore) as employed for determining the opacity of the film. The absorbance of the sample was read at $600 \mathrm{~nm}(4 \mathrm{~cm} \times 1 \mathrm{~cm})$ by measuring light transmittance (Tunc and Duman, 2010). The measurement was performed in triplicates, and opacity was calculated as follows:

Eq (2):

Opacity $(\%)=A 600_{\mathrm{nm}} / \mathrm{X}$

Where, $\mathrm{A} 60_{\mathrm{nm}}$ is the absorbance at $600 \mathrm{~nm}$ and $\mathrm{X}$ is the film thickness $(\mathrm{mm})$.

\subsubsection{Thickness}


The thickness of the synthesized bioplastic was measured by using a digital vernier caliper. The thickness was checked at different parts of the bioplastic film, and the average was calculated (Oluwasina et al., 2019).

Average Thickness=Sum of the measured values/number of readings

\subsubsection{Solubility in water}

Solubility determination was carried out according to the method of Lin et al. (2010). Films of 2-cm diameter were incubated in a hot air oven at $105^{\circ} \mathrm{C}$ for $24 \mathrm{~h}$. The weighed samples (wi) were transferred to $50 \mathrm{ml}$ of distilled water and incubated as described. The dry mass (wf) of the samples was determined under prescribed conditions. The solubility (\%) of the bioplastic films was calculated from the results of triplicate experiments.

Eq (3):

Solubility $(\%)=$ wi-wf $/$ wix 100

Where, $w i$ is the initial mass $(\mathrm{g})$ and $w f$ is the final mass $(\mathrm{g})$.

\subsubsection{Morphology and features of the bioplastic films}

For scanning electron microscopic (SEM-JSM-IT 200, Tokyo, Japan) observation, the film was sputtered with gold in a metallizer for $3 \mathrm{~min}$. The morphology of the bioplastic samples was visualized by placing two pieces of the film on an aluminium sample holder held perpendicular to each other. The SEM images were captured at a magnification of up to 8000 times. An acceleration voltage of $20 \mathrm{kV}$ was used to visualize the samples (Sudharsan et al., 2016).

\subsubsection{Mechanical testing using universal testing machine (UTM)}

The mechanical property, i.e., the tensile strength of the bioplastic sample, was tested using a UTM (Instron Machine Series 3369) at room temperature (Saberi et al., 2017).

\subsubsection{Fourier transform infrared (FT-IR) spectroscopy}

The FT-IR spectra of the bioplastics were analyzed using an FT-IR instrument (Perkin-Elmer Model 1000) fitted with an attenuated total reflectance attachment. The spectra were observed at the frequency range of $4000 \mathrm{~cm}^{-1}-500 \mathrm{~cm}^{-1}$ (Sudharsan et al., 2016).

\subsubsection{X-ray diffraction (XRD)}

Wide-angle X-ray diffraction (XRD) studies were carried out using a diffractometer (Phillips Model PW, 1830) containing copper and a target material (Dos Santos et al., 2016; Sudharsan et al., 2016). 


\subsubsection{Thermogravimetry/differential thermal analysis (TG- DTA)}

The samples were subjected to thermal stability testing using a TG analyzer (Netzsch STA449F3) heated gradually at the rate of $10^{\circ} \mathrm{C} / \mathrm{min}$ from $100^{\circ} \mathrm{C}$ to $600^{\circ} \mathrm{C}$ under nitrogen atmosphere (Thammahiwes et al., 2018).

\subsubsection{Biodegradability test}

For biodegradability testing, the assembled bioplastic samples were dried at $45^{\circ} \mathrm{C}$ for $24 \mathrm{~h}$. Samples weighing $5 \mathrm{~g}$ were weighed and buried with municipal solid waste fertilizer containing leaves, cow dung, food, paper, wood-waste, composting seeds, urea, and water (Muller, 2005). After 7 days, the bioplastic films were separated from the municipal compost and SEM images of the specimen were taken after visual examination (Marichelvam et al., 2019). The biodegradability was measured follows:

Eq (4):

Weight Loss $(\%)=($ Wo - W $) /$ Wo $] \times 100$

Where, Wo and W are the weights of the samples before and after the test, respectively.

\section{Results}

The bioplastic films prepared with different ratios of FS with CS using the casting method are illustrated in Supplementary Figure 1.

Texture, color, and hot water solubility of the bioplastic films were tested using sensory evaluation methods, such as visual examination and textural evaluation using the eyes and hands, respectively. The texture of CS was a fine powder, while FS was mildly coarse. CSFS1 and CSFS2 were also mildly coarse powders since FS powder had contributed to their coarseness. The color of CS was pure white, while FS was yellowish white in color. CSFS1 and CSFS2 also appeared as yellowish white powders owing to the presence of FS. When the hot water solubility of CS was tested, it showed gel formation within 15 min of heating, whereas FS was insoluble even after 30 min of heating at $90^{\circ} \mathrm{C}$. CSFS1 and CSFS2 formed insoluble gels within 30 min of heating. Similar to texture and color, the CSFS1 and CSFS2 exhibited the property of FS and were insoluble for up to $15 \mathrm{~min}$; however, they later turned into a gel because of the CS content (Table 1). 
Table 1

Texture, color and hot water solubility of bioplastic films

\begin{tabular}{|lllll|}
\hline S.No. & Samples & Texture & Color & Hot water solubility \\
\hline 1 & CS & Fine powder & pure white & Gel formation \\
\hline 2 & CSFS1 & Mildly coarse powder & yellowish white & Insoluble Gel formation \\
\hline 3 & CSFS2 & Mildly coarse powder & yellowish white & Insoluble Gel formation \\
\hline 4 & FS & Mildly coarse powder & yellowish white & Insoluble \\
\hline
\end{tabular}

Moisture contents were observed in the order of CS $(15 \pm 0.95 \%)>C S F S 1(11.4 \pm 0.33 \%)>C S F S 2(8.2 \pm$ $0.16 \%)>\mathrm{FS}(4.2 \pm 0.09 \%)$, as illustrated in Figure 1 .

The opacity of the produced biofilms is presented in Supplementary Figure. 2. Maximum opacity was observed for FS (8.045 $\pm 0.08 \%)$, followed by CSFS2 ( $4.14 \pm 0.16 \%)$, CSFS1 (2.45 $\pm 0.08 \%)$, and CS $(2.21 \pm 0.06 \%)$.

The average thickness of the synthesized bioplastic films ranged from $0.0322 \pm 0.001 \mathrm{~mm}$ to $0.194 \pm$ $0.001 \mathrm{~mm}$. FS had the highest average thickness $(0.194 \pm 0.001 \mathrm{~mm})$, followed by CSFS2 $(0.0938 \pm 0.002$ $\mathrm{mm})$ and CSFS1 $(0.0420 \pm 0.001 \mathrm{~mm})$, while CS had the lowest average thickness $(0.0322 \pm 0.002 \mathrm{~mm})$, as shown in Table 2.

Table:2 Solubility of different bioplastic film

\begin{tabular}{|lllll|}
\hline S. No & Sample & Initial Value & Final value & Solubility in Percentage(\%) \\
\hline $\mathbf{1}$ & CS & 0.25 & 0.17 & 32 \\
\hline $\mathbf{2}$ & CSFS1 & 0.31 & 0.23 & 23 \\
\hline $\mathbf{3}$ & CSFS2 & 0.15 & 0.12 & 20 \\
\hline $\mathbf{4}$ & FS & 0.40 & 0.39 & 2.5 \\
\hline
\end{tabular}

The observed solubility of the synthesized bioplastic films ranged from $2.5 \%$ to $32 \%$. CS had the highest solubility of $32 \%$, with a soluble weight of $0.08 \mathrm{~g}$ after 7 days of incubation (Table 3 ).

Table: 3 Thickness of the different bioplastic films 


\begin{tabular}{|lll|}
\hline S. No & Sample & Thickness $(\mathrm{mm})$ \\
\hline 1 & CS & $0.0322 \pm 0.001$ \\
\hline 2 & CSFS1 & $0.0420 \pm 0.001$ \\
\hline 3 & CSFS2 & $0.0938 \pm 0.002$ \\
\hline 4 & FS & $0.194 \pm 0.001$ \\
\hline
\end{tabular}

Water absorption test revealed that CS (60 -70 \%) had higher absorption capacity than other bioplastic films, whereas CSFS1 and CSFS2 exhibited comparable absorption patterns (55-60\% and 40-50\%, respectively). On the other hand, FS showed minimal (30-40\%) water absorption capacity (Supplementary Figure. 3).

The SEM images of CS indicated a rough surface. The adhesion between the CS matrix and the FS powder of the bioplastic films was also visible in the images. The surface of CSFS1 was smooth and continuous, which is a highly preferred morphology without cavities, edges, or holes. Conversely, the surface of CSFS2 exhibited a rough and irregular surface, which is an unfavorable morphology with cavities. FS surface structure was mildly rough and irregular, which is a slightly unpleasant morphology (Figure. 2).

Figure 3, illustrates the tensile strength of the bioplastic films. The highest tensile strength $(10.1 \pm 0.05$ $\mathrm{MPa})$ was observed for FS, whereas the lowest $(3.9 \pm 0.1 \mathrm{MPa})$ was noted for $\mathrm{CS}$. The other samples, namely CSFS1 $(6.06 \pm 0.05 \mathrm{MPa})$ and CSFS2 $(8.1 \pm 0.1 \mathrm{MPa})$, possessed moderate tensile strength. The FTIR spectrum was recorded in the range of $4000-500 \mathrm{~cm}^{-1}$. The analysis signified that the CS film had characteristic peaks at $1645,1543,1149,1022$, and $661 \mathrm{~cm}^{-1}$, which corresponds to functional bonds (amide I, II). The FT-IR spectrum of CSFS1 displayed peaks at 2927, 1645, 1546, 1411, 850, and 600$1000 \mathrm{~m}^{-1}$, which corresponds to alkanes, amides (1645 and $\left.1546 \mathrm{~cm}^{-1}\right)$, aromatics (1411 and $850 \mathrm{~cm}^{-1}$ ), and phosphates. CSFS2 presented FT-IR peaks at 1739, 2927, 1647, 600-1000, and $1421 \mathrm{~cm}^{-1}$ which corresponds to esters, alkanes, amides, phosphates, and aromatics. FS showed peaks at 1510, 1269, 742, 520 , and $570 \mathrm{~cm}^{-1}$ which corresponds to amides, esters, phosphates, and alkyl halides (Figure. 4).

XRD studies were performed to analyze the crystalline phase of the bioplastic films and the patterns. The XRD patterns were examined with $2 \theta$ scans from $10^{\circ}$ to $100^{\circ}$. Phase identification was achieved by comparing the samples to standards of JCPDS 00-009-0432 for hexagonal hydroxyapatite (HAp) structure (calcium phosphate hydroxide $\mathrm{Ca}_{5}\left(\mathrm{PO}_{4}\right)_{3}(\mathrm{OH})$ ). CSFS1 showed $2 \theta$ values of $22.8^{\circ}, 27.5^{\circ}, 40.1^{\circ}$, $63.1^{\circ}$, and $78.2^{\circ}$, followed by (hkl) $111,102,221,502$, and 522. CSFS2 images depicted $2 \theta$ values of $25.6^{\circ}, 32.1^{\circ}, 52.1^{\circ}$, and $66.3^{\circ}$, followed by (hkl) $201,112,402$, and 413 . The FS sample demonstrated $2 \theta$ values of $25.7^{\circ}, 34.1^{\circ}, 53.1^{\circ}, 65.1^{\circ}$, and $78.2^{\circ}$, followed by (hkl) $002,202,004,511$, and 522 . However, the CS sample was not found in the JCPDS 00-009-0432 file due to the absence of hydroxyapatite (Figure. 5). 
Thermal analysis of the bioplastic films was conducted using thermogravimetric analysis. TGA of FS possessed the highest thermal stability of $328.8^{\circ} \mathrm{C}$. However, the thermal stabilities of the other samples were inferior. CSFS1 had a maximum thermal stability of $278.741^{\circ} \mathrm{C}$, while for CSFS2 and CS it was $273.516^{\circ} \mathrm{C}$ nd $253.7^{\circ} \mathrm{C}$, respectively. The TG curves were associated with a DTA curve to determine the thermal stability. Thermal weight loss was observed in three stages, namely primary, secondary, and tertiary. The primary stage had a temperature range of $0{ }^{\circ} \mathrm{C}-300^{\circ} \mathrm{C}$, while the secondary and tertiary stages had temperature ranges of $300{ }^{\circ} \mathrm{C}-350^{\circ} \mathrm{C}$ and $350^{\circ} \mathrm{C}-600^{\circ} \mathrm{C}$, respectively. Sudden maximum weight loss was observed in the secondary stage, while the other stages exhibited gradual and minimal weight loss. Though temperature variations were witnessed in all stages, maximum weight loss occurred in the secondary stage in all the samples (Supplementary Figure 4).

The bioplastic films were subjected to degradation for a period of 7 days, at the end of which they were visualized using SEM. The surface structure exhibited substantial variations, and the material had lost its evenness. The bioplastic films presented surface irregularities, which revealed fungal growth and indicated degradation, as witnessed in the SEM images (Figure. 6). The fungal spores, which were identified as Aspergillus sp., caused thinning of the films and suggested biodegradation. Among all the tested samples, CS exhibited the highest degradation (60\%), followed by CSFS1 (50\%) and CSFS2 (38 $\%)$. On the other hand, FS underwent the least degradation (28\%). The percent degradation of all the four sample types is shown in Figure. 7.

\section{Discussion}

Biopolymer-based plastics are generally termed as bioplastics. These are manufactured from diverse sources such as polysaccharides, lipids, and proteins (Hernandez-Izquierdo and Krochta, 2008). Starch and natural fibers constitute the chief raw materials for the synthesis of bioplastics. They have received immense attention owing to various advantages such as biodegradability, eco-friendly nature, costeffectiveness, and abundant availability (Madhu et al., 2018; Syafri et al., 2020). Biodegradable starch can be processed by employing various methods such as blow molding and casting. Many researchers have attempted to study the potential of starch-based bioplastics (Teixeira et al., 2009: Abral et al., 2018). Starch exhibits polymer-like properties upon hydrolysis and is composed of unbranched molecules of glucose and branched molecules of amylase and amylopectin (Mweta, 2009). In the present study, synthesis of bioplastics containing a combination of FS with CS was attempted.

The results of sensory evaluation suggested that the CS-based bioplastics were in the form of a fine powder, while the other types (CSFS1, CSFS2, and FS) were granular in nature. Awonusi et al. (2007) stated that the granular nature of FS, CSFS1 and CSFS2 is probably due to the presence of phosphates and amide I and III groups.

The color of the synthesized bioplastics showed that CS type was pure white, while the others were yellowish white. The yellowish white appearance of the FS, CSFS1 and CSFS2 was due to the presence of phosphate groups present in the fish scales (Awonusi et al., 2007). 
The hot water solubility test indicated gel formation by CS within 15 min of boiling. CSFS1 and CSFS2 formed insoluble gels, whereas FS was completely insoluble. The reason for the insolubility could not be fathomed, and even previous researchers had encountered difficulties in this regard. All the above results are in agreement with the observations of Shah et al. (2019) and Oluwasina et al. (2019).

The moisture contents of the bioplastic films were $15 \pm 0.95 \%$ and $4.29 \pm 0.09 \%$ for CS and FS, respectively. CSFS1 $(11.4 \pm 0.33 \%)$ and CSFS2 $(8.2 \pm 0.16 \%)$ had nominal moisture contents when compared with CS and FS.CS, CSFS1 and CSFS2 showed results similar to Garrido et al. (2014) but the range was much lesser than FS. The addition of glycerol enhanced the moisture absorption capability of the films. Glycerol is hygroscopic in nature, which facilitated the storage of water molecules. This observation is in accordance to the results of Lee et al. (2013) who reported that glycerol enhanced the absorption properties of the biopolymer. Additionally, FS is hygroscopic in nature, which influenced the water absorption. Therefore, FS displayed the highest moisture absorption capability, which was greater than that documented by earlier studies (Lee et al., 2013; Garrido et al., 2014). However, Oluwasina et al. (2019) opined that bioplastics used in food packaging should not exhibit moisture absorption to prevent food spoilage. Hence, bioplastic films with reduced absorption properties are deemed advantageous for this application. With this view in mind, it can be stated that CSFS1 is highly suited for use in food packaging.

In this study, FS possessed the highest thickness $(0.194 \pm 0.001 \mathrm{~mm})$ because of the presence of the FS powder, followed by CSFS2 $(0.0938 \pm 0.002 \mathrm{~mm})$, CSFS1 $(0.0620 \pm 0.001 \mathrm{~mm})$, and CS $(0.0322 \pm 0.001)$. A previous study that used myofibrillar protein-based bioplastics with fish gelatin observed thicknesses ranging from $0.034 \mathrm{~mm}$ to $0.036 \mathrm{~mm}$ (Arfat et al., 2014). Though CS had least thickness, CSFS2 had a higher thickness due to the influence of FS. Likewise CSFS2 had higher thickness than CSFS1 due to the higher concentration of FS. Bioplastic film thickness is dependent on its composition and method of processing (Garcia and Sorbal, 2005). The reduced thickness in the current study could be associated with the high concentrations of amylose and amylopectin present in the starch (CS). The thickness could also be attributed to the presence of more solids in the bioplastic solution and the consequent formation of a viscous paste, resulting in a thicker film. A similar thickness $(0.099$ to $0.1599 \mathrm{~mm})$ was reported by Santana et al. (2018) for starch-based bioplastics.

The water solubility of bioplastic films is entirely dependent on polymer structure and intermolecular bonds (Kaewprachu and Rawdkuen, 2014). Glycerol is hydrophilic in nature and is used as a plasticizer to ensure bioplastic solubility. In addition, its hydrophilic nature increases the mobility of the peptide chains and contributes to solubility (Ekrami and Emam-Djomeh, 2014). The least solubility of $2.5 \%$ exhibited by FS is lower than that reported by a other studies (Monterrey-Quintero and Sobral, 2000). The dry matter in the film mesh causes hardness and enhances the traction resistance while reducing its solubility (Neves et al., 2019).

The opacity of the samples is dependent on the composition, origin, and thickness of starch. The greater content of amylose in the samples might be the reason for their higher thickness (Basiak et al., 2017). 
This observation is in relation to starch. However, Lin et al. (2011) opined that the chief building block of FS is collagen, which also contributes to thickness. In the present study, FS had the highest thickness while CS had the least thickness, which can be correlated to opacity. FS had the highest opacity (8.05 \pm $0.08 \%$ ), followed by CSFS2 ( $4.14 \pm 0.16 \%)$, CSFS1 ( $2.45 \pm 0.08 \%)$, and CS $(2.16 \pm 0.06 \%)$. Zavareze et al. (2012) explained the importance of opacity in the coating of food surfaces. However, transparent films have applications as stressed by Santana et al. (2018). Decreased opacity indicates higher transparency, alluding that CSFS1 is the most suitable owing to its transparency.

Water absorption kinetics of the bioplastic films reveals the moisture tolerance and the filling of water within the films. CS displayed the highest absorption (50-70\%), followed by CSFS1 (30-50 \%), CSFS2, and FS (20-40\%) within 0-22 min. The higher absorption kinetics leads to the swelling of the films, which opens more pores and contributes to further accumulation of water. However, the fine powdery nature prevents the excess storage of water. Meanwhile, the mild granular powders facilitate gradual absorption but have high water storage capacity in their pores. These results are in agreement with earlier works on methyl cellulose-montmorillonite films (Tunc and Duman, 2010) and whey proteins (Galus and Kadzi, 2016).

SEM micrographs showing intact starch granules signified incomplete gelatinization during the film formation. Cross-sections of the films revealed the presence of an irregular structure with ridges and grooves. These grooves may be the result of microbubble formation during the gelatinization, which was also present in the bioplastic films synthesized by Santana et al. (2018). Minor discontinuities were observed in all the SEM images at $500 \mathrm{x}$ magnification, and these discontinuities were identified as cracks. These cracks may compromise the structural integrity, thereby causing alterations in functional properties (Souza et al., 2004).

In this study, FS demonstrated higher tensile strength when compared with CSFS1, CSFS2, and CS. Elimination of the unrequired organic compounds and collagen from the FS powder enhanced the mechanical and thermal properties of the films (Chiarathanakrit et al., 2018). An increase in the amount of FS powder resulted in a slight decrease in the tensile strength of the wheat gluten-based bioplastic film (Thammahiwes et al., 2017). Bioplastics should have sufficient tensile strength to ensure their integrity when used as packaging materials.

FT-IR analysis of HAp powder was performed in the range of $4,000-500 \mathrm{~cm}^{-1}$ to detect the presence of various functional groups. The results were supported by the FT-IR spectra (Figure 7). Wave numbers of 1645,1546 , and $1647 \mathrm{~cm}^{-1}$ were assigned as the peaks for amides I, II, and III of collagen type I (Chuaychan et al., 2016). The band situated at the wave number of $1037 \mathrm{~cm}^{-1}$ was found in the CSFS1 and CSFS2 samples. Similarly, wave numbers were observed in the range of $1036-1039 \mathrm{~cm}^{-1}$, signifying interactions between the plasticizer (OH group of glycerol) and the film structure (Hoque et al., 2011).

Similar spectra were obtained for all fish protein isolates and gelatin films in the range of $1800-600$ $\mathrm{cm}^{-1}$, covering amide-I, II, and III. Amide A and B bands were observed at 2926-2928 $\mathrm{cm}^{-1}$ (Muyonga et 
al., 2004; Ahmad \& Benjakul, 2011). Likewise, for the CSFS2 samples, wave numbers were observed at 3250 and $2927 \mathrm{~cm}^{-1}$. The peak of amide I was found in the CSFS1, CSFS2, and FS films. Absorption in the range of $1600-1700 \mathrm{~cm}^{-1}$ (amide I) is mentioned in the literature as key for protein secondary structure (Muyonga et al., 2004). Earlier reports also suggest the presence of HAp in the FS composition (Zhu etal., 2012; Garrano et al., 2012). HAp is present mainly due to the inorganic content of FS, while their absorption peaks represent phosphate groups (550-610 and $1000-1100 \mathrm{~cm}^{-1}$ ) and carbonate anions $\left(871,1400\right.$, and $1460 \mathrm{~cm}^{-1}$ ) (Chin-San Wu, 2019). It is known that carbonate-substituted HAp is of three types, depending on the substitution site: hydroxyl site (A-type), phosphate site (B-type), and both sites (AB-type) (Koutsopoulos, 2002; Tonegawa et al., 2010).

Complete crystallization of the powders was confirmed based on the sharp peak intensities and wellresolved peaks in the XRD spectrum (Panda et al., 2014). XRD analysis of the bioplastic films validated the HAp structure (JCPDS 00-009-0432) (hydroxyapatite; calcium phosphate hydroxide, $\mathrm{Ca}_{5}\left(\mathrm{PO}_{4}\right)_{3}(\mathrm{OH})$. The hexagonal HAp structure of CSFS1, CSFS2, and FS (111, 102, 221, 502, 522, 201, 112, 402,413, 002, $202,004,511$, and 522 obtained in this study was compared with that reported by Mondal et al. (2010) for confirmation. Our results are also in accordance with earlier reports by Chuaychan et al. (2016). FS contains collagen fibrils and calcium phosphates, particularly HAp crystals $\left(\mathrm{Ca}_{10}\left(\mathrm{PO}_{4}\right)_{6}(\mathrm{OH})_{2}\right)(\mathrm{Okuda}$ et al., 2009).

The relationship between the temperature and properties of the synthesized bioplastic films was assessed. The major constituents of FS are collagen, connective tissue proteins, and proteinaceous molecules such as guanine, glycine, alanine, and hydroxyproline (Mondal et al., 2010). TGA curves of the bioplastic films showed thermal stability in the range of $250^{\circ} \mathrm{C}-330^{\circ} \mathrm{C}$. The TG-DTA plots of the samples showed weight loss in three stages, as previously reported (Sobczak-Kupiec and Wzorek, 2012). Weight loss in the primary stage is generally due to the loss of bound water. The weight loss in the secondary stage is due to a complex process that involves saccharide ring dehydration and chitosan depolymerization and denaturation (Wan et al., 2009). Total denaturation of the polymers occurs, which leads to complete weight loss in the tertiary stage (Wan et al., 2009). In the secondary stage, complete decomposition of starch and organic compounds present in the FS powder occurs, which results in maximum weight loss. Similar weight loss pattern was observed in a previous work that focused on bioplastic films from shrimp shell waste and wheat gluten (Kumari et al., 2016).A number of other works on FS and collagen also reported weight loss during the secondary stage in a temperature range of $250^{\circ} \mathrm{C}-330^{\circ} \mathrm{C}$. Their findings disclose that weight loss in this stage could be due to the cleavage of organic components (Tampieri, et al., 2003).

In earlier studies by Thammahiwes et al. (2017), FS of Lates calcarifer in combination with wheat gluten was used. The maximum observed tensile strength identified in their research was $7.51 \mathrm{MPa}$. In the present investigation, we observed the highest tensile strength of $10.1 \pm 0.05 \mathrm{MPa}$ by using corn starch based bioplastics in multiple fish scles. 
Biodegradability is a key feature of next-generation plastics, and the European Committee for Standardization specifies $90 \%$ degradation within 6 months (Soroudi and Jakubowicz, 2013). In the biodegradability test, degradation was noticed after 7 days of treatment with organic waste. Degradation was affected by the growth of Aspergillus sp. The SEM images showed thinning of the bioplastic films mediated by the Aspergillus sp. spores, which confirms the biodegradable nature of the synthesized bioplastic films. In this case, the fungus facilitating the degradation was naturally present in the organic waste. However, in an earlier study (Abdullah et al., 2018), A. niger were artificially introduced. These findings indicate that bioplastics can be naturally degraded without the use of chemicals or other methods of degradation such as photodegradation. Conventional plastics meant for single use can be replaced with these easily degradable bioplastic films.

In the present study, CS showed the fastest degradation (12 days) while FS showed slowest degradation (no.of days). CSFS1 (no.of days) and CSFS2 (no.of days) showed moderate rates of degradation. The complex polymer chains experienced enzymatic cleavage and were subsequently reduced to short chains of monomers, dimers, and oligomers. These shortened chains act as carbon sources by easily passing through the bacterial membranes. Increased availability of carbon in CS could enhance biodegradation by hydrolysis and subsequent molecular weight loss. The resultant smaller molecules are susceptible to enzymatic attack, causing rapid biodegradation (Bhardwaj et al., 2013).

In a former study by Abdullah et al. (2019), the fungal species A. niger was introduced artificially to induce biodegradation. However, in this study, Aspergillus sp. naturally present in the soil caused the degradation. This result indicates that bioplastics can be naturally degraded without the addition of chemicals or other inducers.

\section{Conclusion}

In this research, FS and CS were used in different combinations to synthesize bioplastic films. FS and CS applied in the ratio of 1:3 exhibited excellent physical, chemical, and mechanical properties. In addition, the study confirmed that the synthesized plastics are easily biodegradable. Therefore, these bioplastics can be used as viable alternatives to the hazardous petroleum-based conventional plastics. The ecofriendly bioplastics can be used an agricultural field. However, standardization of technology is required prior to commercial production.

\section{Declarations}

Ethics approval and consent to participate: Not applicable

Consent to publication: Not applicable

Authors Contributions: P. Surya: Research hypothesis, Methodology, Investigation, Writing - original draft, Visualization, Validation. A. Sundaramanickam: Conceptualization, Supervision, Data curation, Data 
validation, Writing - review \& editing. A. Nithin: Conceptualization, Methodology, Writing - original draft, Data validation. P. Iswarya: Data validation, review \& editing.

Funding Information: This study was supported by a research project "Seawater Quality Monitoring (SWQM)" 317 from Ministry of Earth Sciences (MoES), Government of India (Project File No.MoES / ICMAM-PD/ME/CAS318 MB/53/2017).

Competing of interest: The authors declare that they have no conflict of interest

Availability of data and materials: The current work was funded by the Ministry of Earth Sciences, Government of India. Therefore, the financial institution holds the rights. Data will be available on request

\section{Acknowledgements}

This research was supported by a research grant from Ministry of Earth Sciences (MoES), National Centre for Coastal Research, Government of India. All the authors acknowledge authorities of Annamalai University and for providing necessary facilities. The authors wish to thank Prof. T. Balasubramanian for his excellent technical support.

\section{References}

1. Abdullah, A.H.D., Pudjiraharti, S., Karina, M., Putri, O.D. and Fauziyyah, R.H., 2019. Fabrication and Characterization of Sweet Potato Starch-based Bioplastics Plasticized with Glycerol. Journal of Biological Sciences, 19(1), pp.57-64.

2. Abral, H., Putra, G.J., Asrofi, M., Park, J.W. and Kim, H.J., 2018. Effect of vibration duration of highultrasound applied to bio-composite while gelatinized on its properties. Ultrasonics sonochemistry, 40, pp.697-702.

3. Ahmad, M. and Benjakul, S., 2011. Characteristics of gelatin from the skin of unicorn leatherjacket (Aluterus monoceros) as influenced by acid pretreatment and extraction time. Food Hydrocolloids, 25(3), pp.381-388.

4. Arfat, Y.A., Benjakul, S., Prodpran, T. and Osako, K., 2014. Development and characterization of blend films based on fish protein isolate and fish skin gelatin. Food Hydrocolloids, 39, pp.58-67.

5. Awonusi, A., Morris, M.D. and Tecklenburg, M.M., 2007. Carbonate assignment and calibration in the Raman spectrum of apatite. Calcified tissue international, 81(1), pp.46-52.

6. Basiak, E., Lenart, A. and Debeaufort, F., 2017. Effect of starch type on the physico-chemical properties of edible films. International journal of biological macromolecules, 98, pp.348-356.

7. Bhardwaj, H., Gupta, R. and Tiwari, A., 2013. Communities of microbial enzymes associated with biodegradation of plastics. Journal of Polymers and the Environment, 21(2), pp.575-579.

8. Chen, Y., Hung, S.T., Chou, E. and Wu, H.S., 2018. Review of polyhydroxyalkanoates materials and other biopolymers for medical applications. Mini-Reviews in Organic Chemistry, 15(2), pp.105-121. 
9. Chiarathanakrit, C., Riyajan, S.A. and Kaewtatip, K., 2018. Transforming fish scale waste into an efficient filler for starch foam. Carbohydrate polymers, 188, pp.48-53.

10. Chuaychan, S., Benjakul, S. and Nuthong, P., 2016. Element distribution and morphology of spotted golden goatfish fish scales as affected by demineralisation. Food chemistry, 197, pp.814-820.

11. Dos Santos, T.P.R., Leonel, M., Garcia, É.L., do Carmo, E.L. and Franco, C.M.L., 2016. Crystallinity, thermal and pasting properties of starches from different potato cultivars grown in Brazil. International journal of biological macromolecules, 82, pp.144-149.

12. Ekrami, M. and Emam-Djomeh, Z., 2014. Water vapor permeability, optical and mechanical properties of salep-based edible film. Journal of food processing and preservation, 38(4), pp.1812-1820.

13. European Bioplastics. Bioplastics Market Data. Available online: https://www.europeanbioplastics.org/ market/ (accessed on 11 March 2021).

14. FAO. 2016. Available online: http://www.fao.org/3/a-i5555e.pdf (accessed on 30 November 2018).

15. Galus, S. and Kadzińska, J., 2016. Moisture sensitivity, optical, mechanical and structural properties of whey protein-based edible films incorporated with rapeseed oil. Food technology and biotechnology, 54(1), pp.78-89.

16. Garrano, A.M.C., La Rosa, G., Zhang, D., Niu, L.N., Tay, F.R., Majd, H. and Arola, D., 2012. On the mechanical behavior of scales from Cyprinus carpio. Journal of the mechanical behavior of biomedical materials, 7, pp.17-29.

17. Gatea, I.H., Abbas, A.S., Abid, A.G., Halob, A.A., Maied, S.K. and Abidali, A.S., 2018.Isolation and characterization of Pseudomonas putida producing bioplastic(Polyhydroxyalkanoate) from vegetable oil waste. Pak J Biotechnol, 15, pp.469-473.

18. Getachew, A., Woldesenbet, F. 2016. Production of biodegradable plastic by polyhydroxybutyrate (PHB) accumulating bacteria using low cost agricultural waste material. BMC Res Notes 9:1-9. https://doi.org/10.1186/ s13104-016-2321-y

19. Hanani, Z.N., Roos, Y.H. and Kerry, J.P., 2012. Use of beef, pork and fish gelatin sources in the manufacture of films and assessment of their composition and mechanical properties. Food Hydrocolloids, 29(1), pp.144-151.

20. Hassan, M.A., Bakhiet, E.K., Hussein, H.R. and Ali, S.G., 2019. Statistical optimization studies for polyhydroxybutyrate (PHB) production by novel Bacillus subtilis using agricultural and industrial wastes. International journal of environmental science and technology, 16(7), pp.3497-3512.

21. Hernandez-Izquierdo, V.M. and Krochta, J.M., 2008. Thermoplastic processing of proteins for film formation-a review. Journal of food science, 73(2), pp.R30-R39.

22. Hoque, M.S., Benjakul, S. and Prodpran, T., 2011. Effects of partial hydrolysis and plasticizer content on the properties of film from cuttlefish (Sepia pharaonis) skin gelatin. Food Hydrocolloids, 25(1), pp.82-90.

23. Ikoma, T., Kobayashi, H., Tanaka, J., Walsh, D. and Mann, S., 2003. Microstructure,mechanical, and biomimetic properties of fish scales from Pagrus major. Journal of structural biology, 142(3), pp.327333. 
24. Ivanova, T.I., Frank-Kamenetskaya, O.V., Kol'tsov, A.B. and Ugolkov, V.L., 2001. Crystal structure of calcium-deficient carbonated hydroxyapatite. Thermal decomposition. Journal of Solid State Chemistry, 160(2), pp.340-349.

25. Kaewprachu, P. and Rawdkuen, S., 2014. Mechanical and physico-chemical properties of biodegradable protein-based films: A comparative study. Food and Applied Bioscience Journal, 2(1), pp.15-30.

26. Kale, G., Kijchavengkul, T., Auras, R., Rubino, M., Selke, S.E. and Singh, S.P., 2007. Compostability of bioplastic packaging materials: an overview. Macromolecular bioscience, 7(3), pp.255-277.

27. Koutsopoulos, S., 2002. Synthesis and characterization of hydroxyapatite crystals: a review study on the analytical methods. Journal of Biomedical Materials Research: An Official Journal of The Society for Biomaterials, The Japanese Society for Biomaterials, and The Australian Society for Biomaterials and the Korean Society for Biomaterials, 62(4), pp.600-612.

28. Kumar, M., Ghosh, P., Khosla, K. and Thakur, I.S., 2018. Recovery of polyhydroxyalkanoatesfrom municipal secondary wastewater sludge. Bioresource technology, 255, pp.111-115.

29. Kumari, S., Rath, P. and Kumar, A.S.H., 2016. Chitosan from shrimp shell (Crangon crangon) and fish scales (Labeorohita): Extraction and characterization Suneeta. African Journal of Biotechnology, 15(24), pp.1258-1268.

30. Lee, R., Pranata, M., Ustunol, Z. and Almenar, E., 2013. Influence of glycerol and water activity on the properties of compressed egg white-based bioplastics. Journal of Food Engineering, 118(1), pp.132-140.

31. Lin, C.C., Ritch, R., Lin, S.M., Ni, M.H., Chang, Y.C., Lu, Y.L., Lai, H.J. and Lin, F.H., 2010. A new fish scale-derived scaffold for corneal regeneration. European cells \& Materials.19, pp.50-57.

32. Lin, Y.S., Wei, C.T., Olevsky, E.A. and Meyers, M.A., 2011. Mechanical properties and the laminate structure of Arapaima gigas scales. Journal of the mechanical behavior of biomedical materials, 4(7), pp.1145-1156.

33. Lopez-Rubio, A., Lagarón, J.M. and Ocio, M.J., 2008. Active polymer packaging of non-meat food products. Smart packaging technologies for fast moving consumer goods, pp.19-32.

34. Madhu, P., Sanjay, M.R., Senthamaraikannan, P., Pradeep, S., Saravanakumar, S.S. and Yogesha, B., 2018. A review on synthesis and characterization of commercially available natural fibers: Part-I. Journal of Natural Fibers, 16(8), pp.1132-1144.

35. Marichelvam, M.K., Jawaid, M. and Asim, M., 2019. Corn and rice starch-based bio-plastics as alternative packaging materials. Fibers, 7(4), p.32.

36. Mathew, S., Brahmakumar, M. and Abraham, T.E., 2006. Microstructural imaging and characterization of the mechanical, chemical, thermal, and swelling properties of starch chitosan blend films. Biopolymers: Original Research on Biomolecules, 82(2), pp.176-187.

37. Mondal, S., Mahata, S., Kundu, S. and Mondal, B., 2010. Processing of natural resourced hydroxyapatite ceramics from fish scale. Advances in Applied Ceramics, 109(4), pp.234-239. 
38. Monterrey-Quintero, E.S. and Sobral, P.J.D.A., 2000. Preparo e caracterização de proteínas miofibrilares de tilápia-do-nilo para elaboração de biofilmes. Pesquisa Agropecuária Brasileira, 35(1), pp.179-189.

39. More, T.T., Yan, S., Tyagi, R.D. and Surampalli, R.Y., 2016. Biopolymer production kinetics of mixed culture using wastewater sludge as a raw material and the effect of differentcations on biopolymer applications in water and wastewater treatment. Water Environment Research, 88(5), pp.425-437.

40. Mostafa, Y.S., Alrumman, Alamri, S.A., Otaif, K.A, Mostafa, M.S., Alfaify, A.M. 2020. Bioplastic (poly-3hydroxybutyrate) production by the marine bacterium Pseudodonghicola xiamenensis through date syrup valorization and structural assessment of the biopolymer. Scientific Reports. 10(1):8815

41. Müller, R.J., 2005. Biodegradability of polymers: regulations and methods for testing. Biopolymers Online: Biology, Chemistry, Biotechnology, Applications, 10, pp.379-384

42. Muyonga, J.H., Cole, C.G.B. and Duodu, K.G., 2004. Characterisation of acid soluble collagen from skins of young and adult Nile perch (Lates niloticus). Food Chemistry, 85(1), pp.81 -89.

43. Okuda, M., Takeguchi, M., Tagaya, M., Tonegawa, T., Hashimoto, A., Hanagata, N. and Ikoma, T., 2009. Elemental distribution analysis of type I collagen fibrils in tilapia fish scale with energy-filtered transmission electron microscope. Micron, 40(5-6), pp.665-668.

44. Olsen, R.L.; Toppe, J.; Karunasagar, I. Challenges and realistic opportunities in the use of by-products from processing of fish and shellfish. Trends Food Science Technology. 2014, 36, 144-151.

45. Oluwasina, O.O., Olaleye, F.K., Olusegun, S.J., Oluwasina, O.O. and Mohallem, N.D., 2019. Influence of oxidized starch on physicomechanical, thermal properties, and atomic force micrographs of cassava starch bioplastic film. International journal of biological macromolecules, 135, pp.282-293.

46. Ooi, C.Y., Hamdi, M. and Ramesh, S., 2007. Properties of hydroxyapatite produced by annealing of bovine bone. Ceramics international, 33(7), pp.1171-1177.

47. Panda, N.N., Pramanik, K. and Sukla, L.B., 2014. Extraction and characterization of biocompatible hydroxyapatite from fresh water fish scales for tissue engineering scaffold. Bioprocess and biosystems engineering, 37(3), pp.433-440.

48. Pati, F., Adhikari, B. and Dhara, S., 2010. Isolation and characterization of fish scale collagen of higher thermal stability. Bioresource technology, 101(10), pp.3737-3742.

49. Penel, G., Leroy, G., Rey, C. and Bres, E., 1998. MicroRaman spectral study of the $\mathrm{PO}_{4}$ and $\mathrm{CO}_{3}$ vibrational modes in synthetic and biological apatites. Calcified tissue international, 63(6), pp.475481.

50. Saberi, B., Thakur, R., Bhuyan, D.J., Vuong, Q.V., Chockchaisawasdee, S., Golding, J.B., Scarlett, C.J. and Stathopoulos, C.E., 2017. Development of edible blend films with good mechanical and barrier properties from pea starch and guar gum. Starch-Stärke, 69(1-2), p.1600227.

51. Santana, R.F., Bonomo, R.C.F., Gandolfi, O.R.R., Rodrigues, L.B., Santos, L.S., dos Santos Pires, A.C., de Oliveira, C.P., Fontan, R.D.C.I. and Veloso, C.M., 2018. Characterization of starch-based bioplastics from jackfruit seed plasticized with glycerol. Journal of food science and technology, 55(1), pp.278286. 
52. Shah, A., Tyagi, S., Bharagava, R.N., Belhaj, D., Kumar, A., Saxena, G., Saratale, G.D. and Mulla, S.I., 2019. Keratin production and its applications: current and future perspective. In Keratin as a Protein Biopolymer (pp. 19-34). Springer, Cham.

53. Soroudi, A. and Jakubowicz, I., 2013. Recycling of bioplastics, their blends and biocomposites: A review. European Polymer Journal, 49(10), pp.2839-2858.

54. Souza, S., Sobral, P.J.D.A. and Menegalli, F.C., 2004. Extração de proteínas miofibrilares de carne bovina para elaboração de filmes comestíveis. Food Science and Technology, 24(4), pp.619-626.

55. Sudharsan, K., Mohan, C.C., Babu, P.A.S., Archana, G., Sabina, K., Sivarajan, M. and Sukumar, M., 2016. Production and characterization of cellulose reinforced starch (CRT) films. International journal of biological macromolecules, 83, pp.385-395.

56. Syafri, E., Kasim, A., Asben, A., Senthamaraikannan, P. and Sanjay, M.R., 2020. Studies on Ramie cellulose microfibrils reinforced cassava starch composite: influence of microfibrils loading. Journal of Natural Fibers, 17(1), pp.122-131.

57. Tampieri, A., Celotti, G., Landi, E., Sandri, M., Roveri, N. and Falini, G., 2003. Biologically inspired synthesis of bone-like composite: Self-assembled collagen fibers/hydroxyapatite nanocrystals. Journal of Biomedical Materials Research Part A: An Official Journal of The Society for Biomaterials, The Japanese Society for Biomaterials, and The Australian Society for Biomaterials and the Korean Society for Biomaterials, 67(2), pp.618-625.

58. Teixeira, E.D.M., Pasquini, D., Curvelo, A.A., Corradini, E., Belgacem, M.N. and Dufresne, A., 2009. Cassava bagasse cellulose nanofibrils reinforced thermoplastic cassava starch. Carbohydrate polymers, 78(3), pp.422-431.

59. Thammahiwes, S., Riyajan, S.A. and Kaewtatip, K., 2017. Preparation and properties of wheat gluten based bioplastics with fish scale. Journal of cereal science, 75, pp.186-191.

60. Thammahiwes, S., Riyajan, S.A. and Kaewtatip, K., 2018. Effect of shrimp shell waste on the properties of wheat gluten based-bioplastics. Journal of Polymers and the Environment, 26(5), pp.1775-1781

61. Tonegawa, T., Ikoma, T., Yoshioka, T., Hanagata, N. and Tanaka, J., 2010. Crystal structure refinement of A-type carbonate apatite by X-ray powder diffraction. Journal of Materials Science, 45(9), pp.24192426.

62. Tunc, S. and Duman, O., 2010. Preparation and characterization of biodegradable methyl cellulose/montmorillonite nanocomposite films. Applied Clay Science, 48(3), pp.414- 424.

63. Villamil, O., Váquiro, H., Solanilla, J.F. 2017. Fish viscera protein hydrolysates: Production, potential applications and functional and bioactive properties. Food Chemistry.224, 160-171.

64. Wan, Y., Lu, X., Dalai, S. and Zhang, J., 2009. Thermophysical properties of polycaprolactone/chitosan blend membranes. Thermochimica Acta, 487(1-2), pp.33-38.

65. Wu, H., Liu, C., Chen, J., Chang, P.R., Chen, Y. and Anderson, D.P., 2009. Structure and properties of starch/a-zirconium phosphate nanocomposite films. Carbohydrate polymers, 77(2), pp.358-364. 
66. Xavier Neves, E.M.P.X., Pereira, R.R., da Silva Pereira, G.V., da Silva Pereira, G.V., Vieira, L.L. and Lourenço, L.D.F.H., 2019. Effect of Polymer Mixture on Bioplastic Development from Fish waste. Boletim do Instituto de Pesca, 45(4), e518.

67. Yang, W., Sherman, V.R., Gludovatz, B., Mackey, M., Zimmermann, E.A., Chang, E.H., Schaible, E., Qin, Z., Buehler, M.J., Ritchie, R.O. and Meyers, M.A., 2014. Protective role of Arapaima gigas fish scales: structure and mechanical behavior. Acta biomaterialia, 10(8), pp.3599-3614.

68. Zhu, D., Ortega, C.F., Motamedi, R., Szewciw, L., Vernerey, F. and Barthelat, F., 2012. Structure and mechanical performance of a "modern" fish scale. Advanced Engineering Materials, 14(4), pp.B185B194.

\section{Figures}

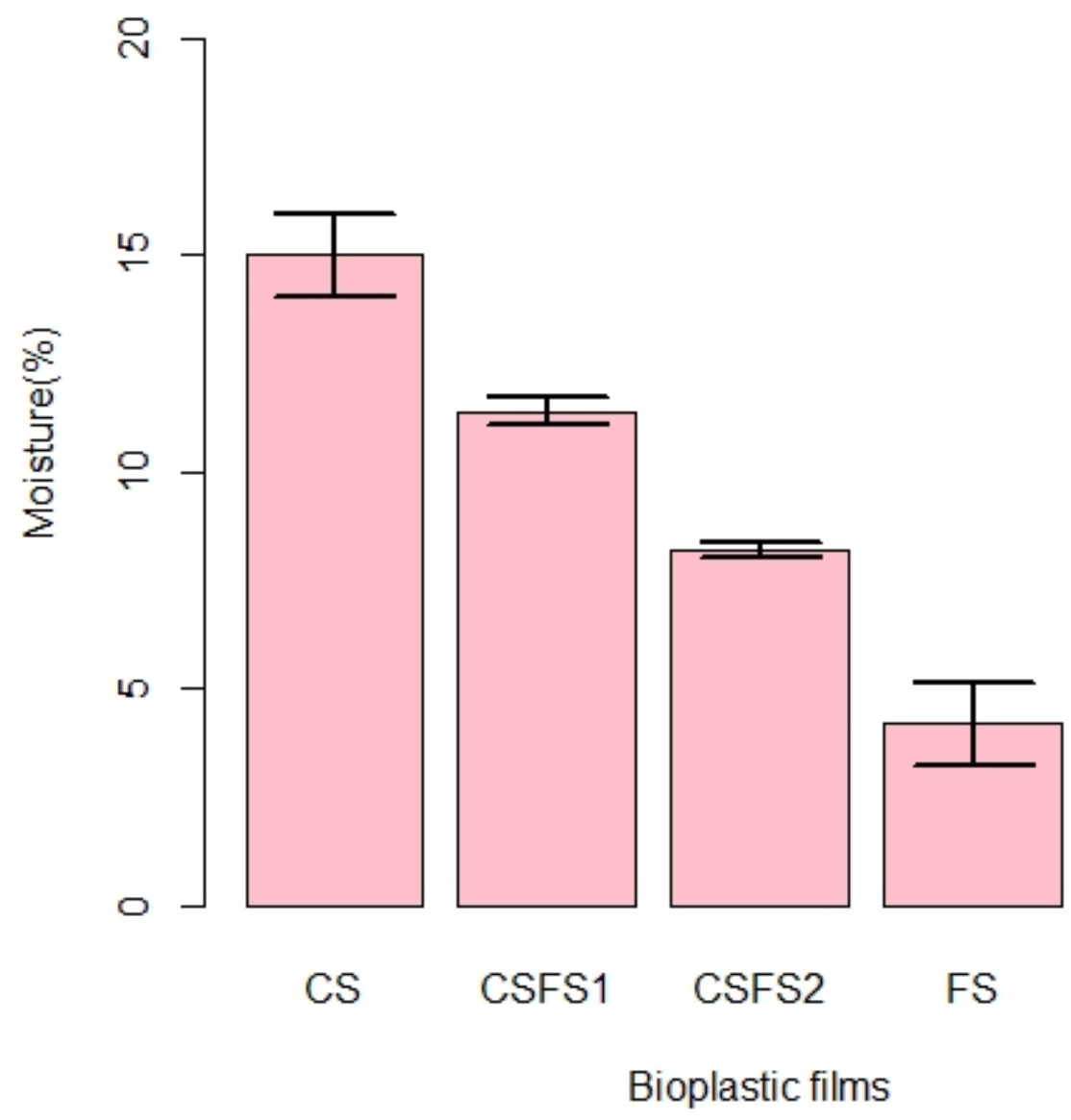

Figure 1

Moisture content of different bioplastic films prepared by the combination of Corn starch and Fish scale 


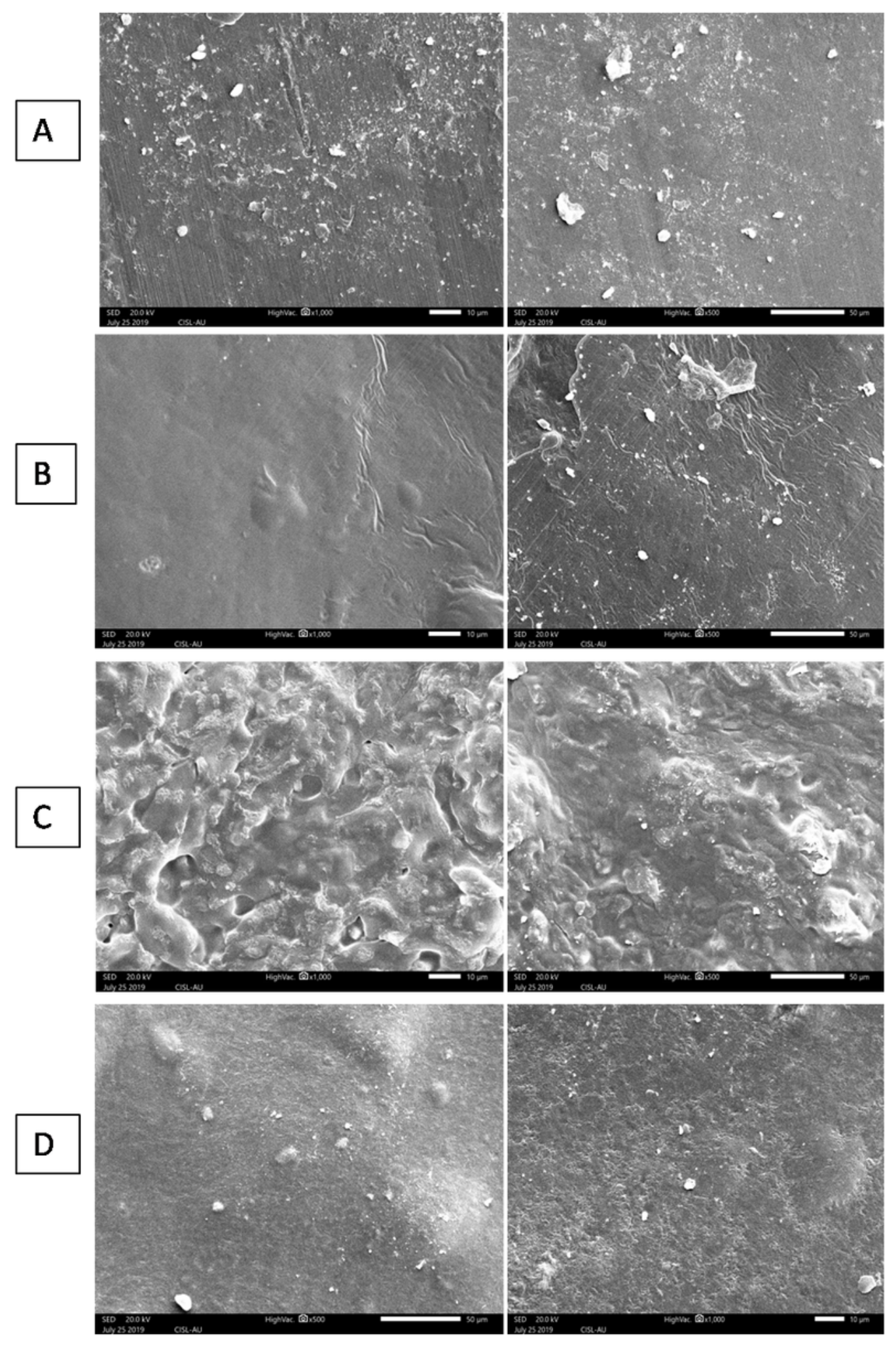

Figure 2

SEM images to visualize the morphology of A. CS, B. CSFS1, C. CSFS2, D. FS 500x magnification 1000x 


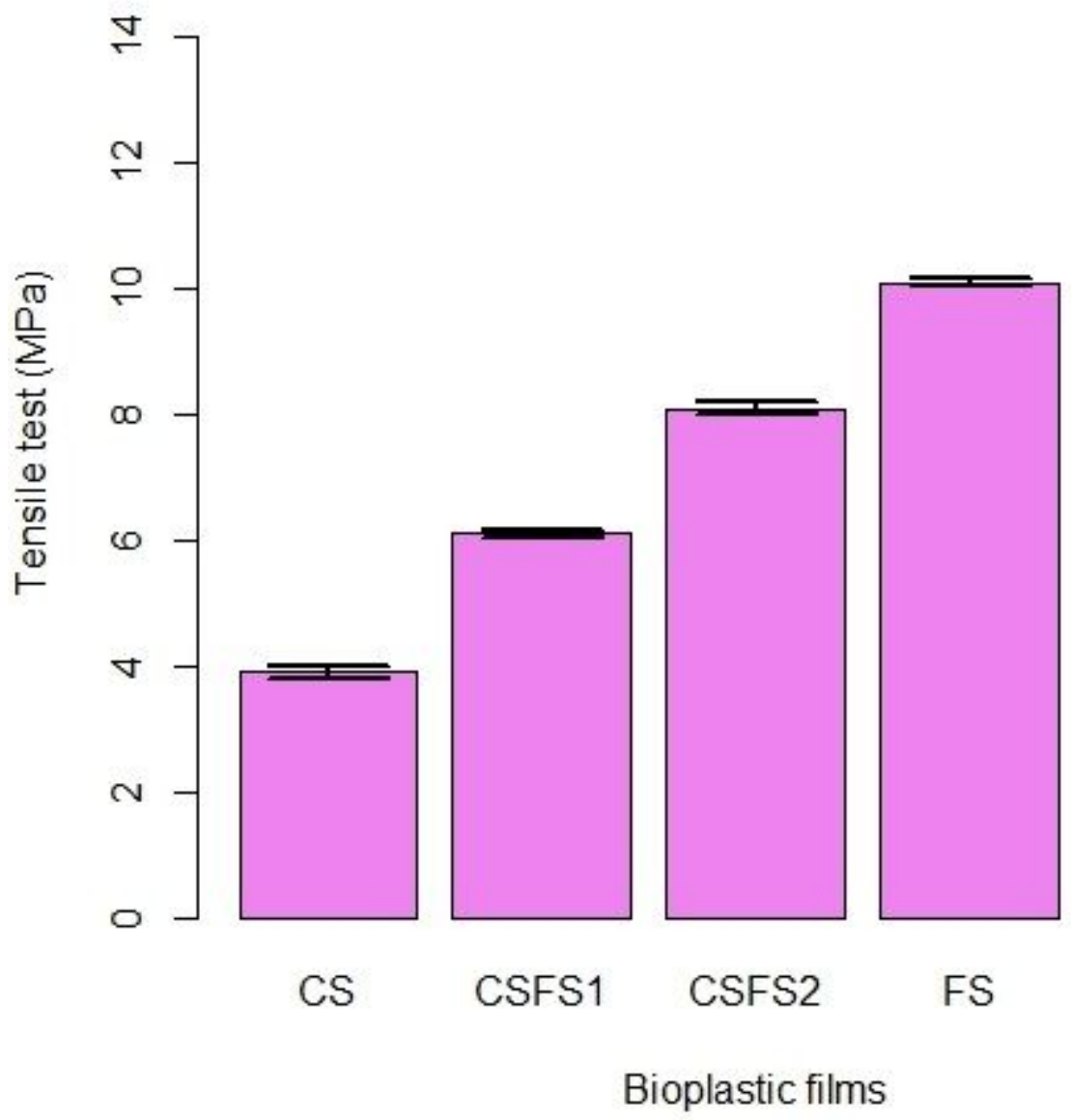

Figure 3

Tensile strength of different bioplastic films 

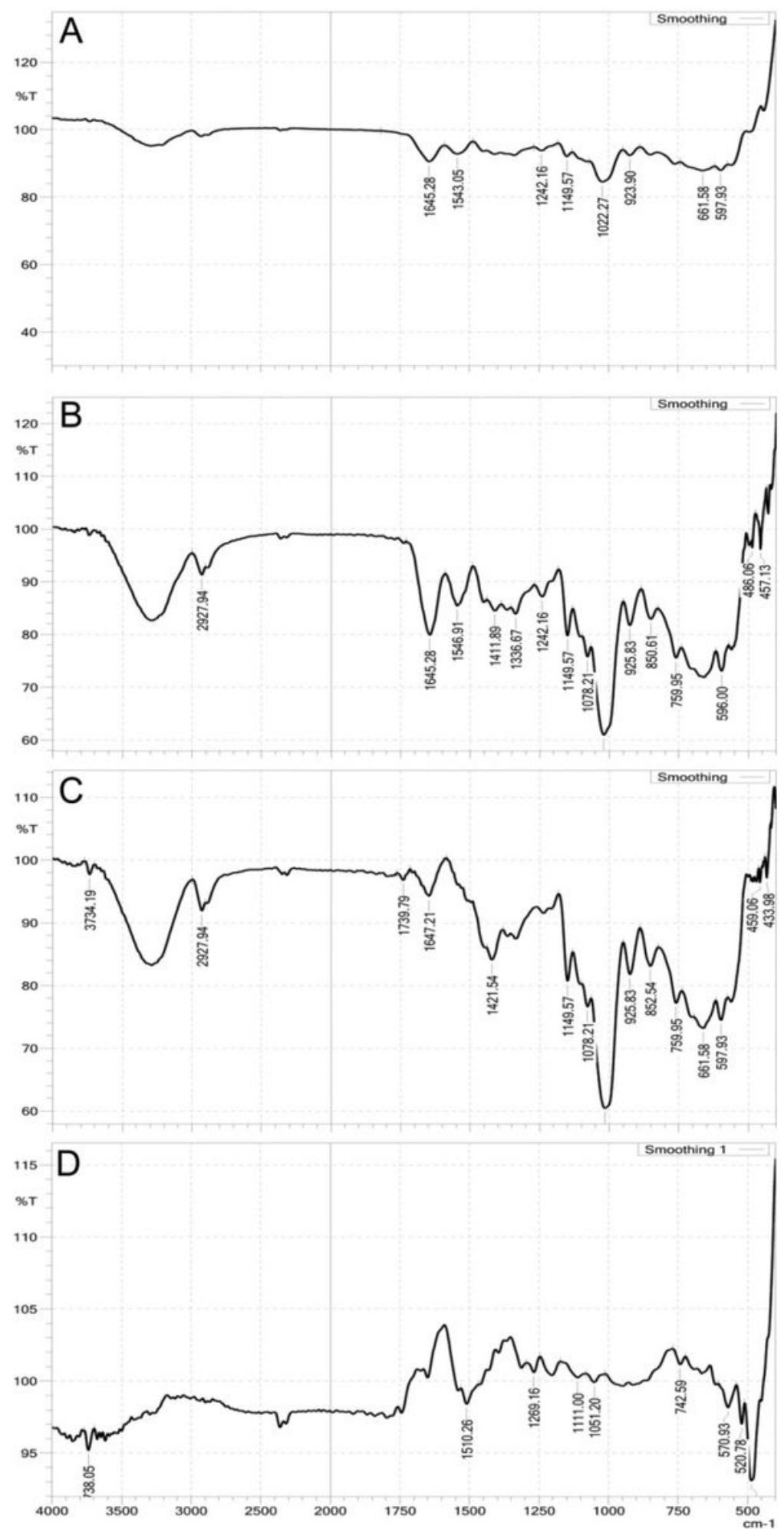

Figure 4

FTIR spectra of bioplastic film of A. CS, B. CSFS1, C. CSFS2, D. FS 

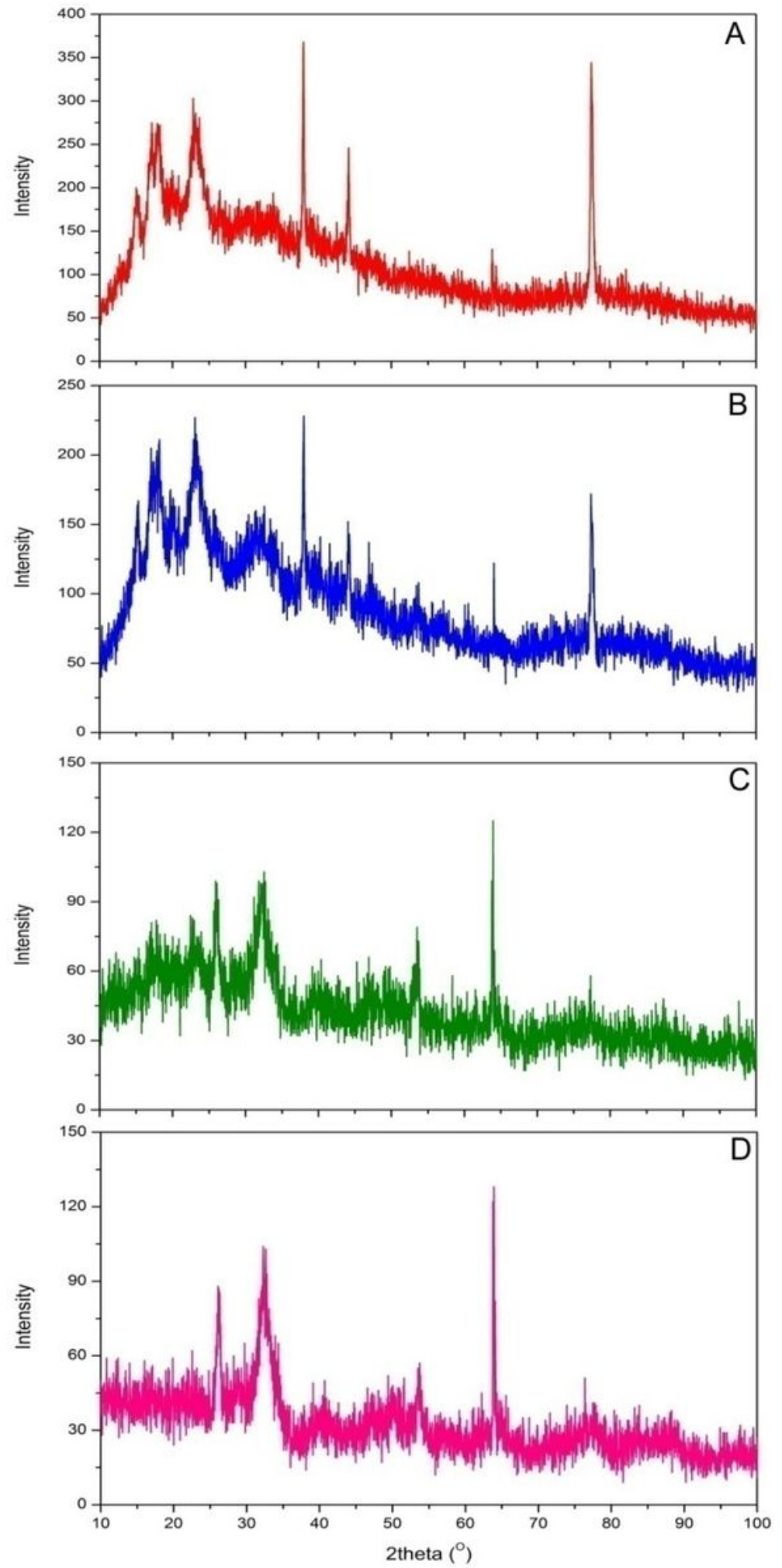

Figure 5

XRD Pattern of bioplastic film A. CS, B. CSFS1, C. CSFS2, D. FS 展

Figure 6 
SEM micrographs showing biodegradability of A. CS, B. CSFS1, C. CSFS2, D. FS 500x magnification $1000 x$

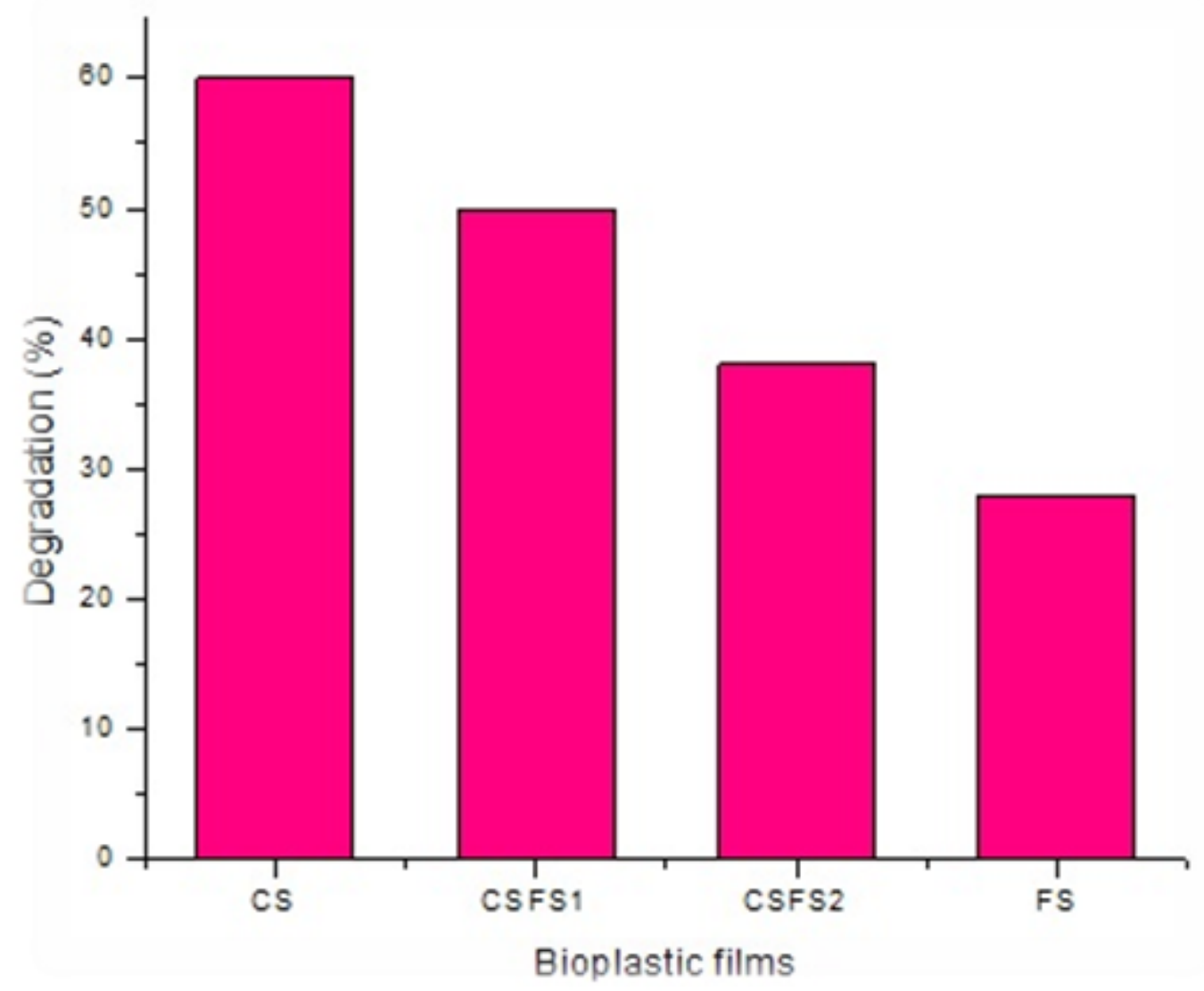

Figure 7

Degradation percentages of the different bioplastic films

\section{Supplementary Files}

This is a list of supplementary files associated with this preprint. Click to download.

- bioplasticsupplimentaryfigures.docx 